\section{Skeie og medarbeidere svarer:}

Som det framgår av kronikken, er frafallet fra LAR-behandling lavt i Norge sammenlignet med de fleste andre land. Dette peker i retning av et akseptabelt tilbud, også sett fra pasientenes ståsted. Etter den norske LAR-retningslinjen er metadon og buprenorfin de opioidene som brukes i vedlikeholdsbehandling, med kombinasjonspreparatet buprenorfin/nalokson (Suboxone) som førstevalg (1). Valg av medikament skal imidlertid vurderes individuelt, og valget vil måtte hensynta både sikkerhet, bivirkninger og behandlingseffekt.

I 2013 brukte $43 \%$ av pasientene i LAR metadon (2). Dersom det foreligger tungtveiende medisinske grunner, kan LAR-pasienter imidlertid få morfinpreparater som vedlikeholdsmedisin, og et mindre antall LAR-pasienter behandles i dag med morfinpreparater med lang virketid. Når «slow-release» morfin brukes som vedlikeholdsmedikament, bruker pasientene en dosering som verken gir vesentlig ruseffekt (eufori) eller abstinens, på samme måte som metadon eller buprenorfin. Det er ikke like god dokumentasjon for bruk av denne type medikament i LAR som for de ordinære LARmedikamentene. Sikkerhetstiltakene rundt vedlikeholdsbehandling med morfin, blant annet bruk av observert inntak, bør være minst det samme som for metadon og buprenorfin.

\section{Ivar Skeie \\ ivar.skeie@gmail.com \\ Thomas Clausen}

Anne Bukten

Ivar Skeie (f. 1952) er ph.d., spesialist i allmennmedisin, overlege i tverrfaglig spesialisert rusbehandling ved DPS Gjøvik, Sykehuset Innlandet, og forsker ved Senter for rus- og avhengighetsforskning, Universitetet i Oslo.

Ingen oppgitte interessekonflikter.

Thomas Clausen (f. 1972) er professor ved Senter for rus- og avhengighetsforskning, Universitetet i Oslo.

Ingen oppgitte interessekonflikter.

Anne Bukten (f. 1977) er postdoktor ved Senter for rus- og avhengighetsforskning ved Universitetet i Oslo.

Ingen oppgitte interessekonflikter.

\section{Litteratur}

. Helsedirektoratet. Nasjonal retningslinje for legemiddelassistert rehabilitering ved opioidavhengighet. Oslo: Helsedirektoratet, 2010.

2. Waal H, Bussesund K, Clausen T et al. Statusrapport 2013. Helseforetakene et godt sted å være? Oslo: Senter for rus- og avhengighetsforskning, Universitetet i Oslo, 2014.

\section{Re: Pasienter som avbryter LAR-behandling - hvordan går det med dem?}

Clausen og medarbeidere konkluderer med at det går dårlig med dem som avbryter LAR-behandling (1). For å unngå at pasienter dropper ut av LAR, mener jeg man trenger leger som tar pasienten seriøst og at pasienten ikke blir straffet for ærlighet med reaksjoner som strengere henteordning og hyppigere urinprøver. Dette er ekstremt viktig hvis man skal løse problema. Folk må bli behandlet med respekt, uansett. Ivar Skeie, som har forsket på LAR, fant i sitt doktorgradsarbeid at selv de som sprekker har godt av LAR (2).

\section{Rune Helgesen \\ hggronnerud@gmail.com}

Rune Helgesen (f. 1962) er miljøterapeut i Gjøvik kommune Ingen oppgitte interessekonflikter.

Litteratur

1. Clausen T, Åsland R, Kristensen O. Pasienter som avbryter LAR-behandling hvordan går det med dem? Tidsskr Nor Legeforen 2014; 134: 1146-9.
2. Universitetet i Oslo. Disputas: Ivar Skeie - Rus-og avhengighetsmedisin www.med.uio.no/klinmed/forskning/aktuelt/arrangementer/disputaser/2012/ skeie-ivar.html (17.6.2014)

\section{Re: Pasienter som avbryter LAR-behandling - hvordan går det med dem?}

Vi er enige $i$ at en god relasjon mellom leger i LAR og pasientene er sentral i LAR-behandling. Det er riktig som påpekt; personer som er i LAR-behandling har lavere risiko for både død, sykelighet og kriminalitet sammenlignet med de som er utenfor LAR (1). Det er derfor sentralt at personer som er avhengige av opioider skal tilbys behandling raskt og uten forsinkende byråkrati, og behandlingen må tilrettelegges slik at pasientene ønsker og klarer å være i behandling. Dersom pasienter utskrives fra LAR, vil de aller fleste leve med høy risiko for tilbakefall til ukontrollert rusbruk, og økt dødelighet (2).

Urinprøvekontroll i LAR er en måte å følge opp behandlingen på, omtrent på samme måte som man måler blodsukker ved diabetes eller INR ved behandling med Marevan. Prøveresultatene brukes til å optimalisere behandlingstilbudet, og gjennom dialog med pasientene, til å motivere for adferdsendring, slik at bedre rusmestring oppnås. Pasienter i LAR skal selvsagt ikke straffes, heller ikke når de har tilbakefall i sin ruslidelse. I sårbare perioder skal ruspasientene tilbys ekstra oppfølging og eventuelt styrking av behandlingstilbudet.

Men, LAR-pasienter er ikke helt som diabetespasienter. De får en medisin som er attraktiv som rusmiddel hos personer utenfor LAR. LAR-pasienter som fortsetter å ruse seg mens de er i LAR, vil kunne fristes til å selge eller bytte bort deler av sine LAR-medisiner. Medisiner på avveie kan forårsake overdosedødsfall hos personer som bruker disse medisinene som rusmiddel utenfor behandling.

Leger i LAR har en kombinert rolle der de både skal bistå sine LAR-pasienter i rehabiliteringsprosessen, og styrke deres behandlingstilbud i perioder med forverring i sykdomstilstanden. I tillegg har leger i LAR et ansvar for å påse at medisinene de forskriver, brukes på rett måte.

I situasjoner med mye rusadferd hos en LAR-pasient, er det legens plikt å påse at LAR-medisiner ikke kommer på avveie, og med det styrke kontrollen med medisinutleveringen. Dette betyr regelmessig observerte inntak av medisin og liten grad av «ta-medhjem» doser. Når rusmiddelbruken kommer under bedre kontroll, og LAR virker stabiliserende, kan man gradvis gi pasienten større ansvar for å oppbevare egne medisiner igjen. Medisineringsregimene i LAR er en balansegang der det gjelder å finne fram til riktig dose der pasienten føler seg frisk uten abstinensplager, motivere for god rusmestring og samtidig giøre sikkerhetsvurderinger underveis.

\section{Øistein Kristensen \\ oistein.kristensen@sshf.no \\ Thomas Clausen \\ Reidun Åsland}

Øistein Kristensen (f. 1945) er overlege ved Avdeling for rus og avhengighetsbehandling, Sørlandet Sykehus.

Ingen oppgitte interessekonflikter.

Thomas Clausen (f. 1972) er professor dr.med. ved Senter for Rus-

og avhengighetsforskning, Universitetet i Oslo.

Ingen oppgitte interessekonflikter.

Reidun Åsland (f. 1956) er psykiatrisk sykepleier og enhetsleder ved poliklinikken for rusbehandling ved Avdeling for rus og avhengighetsbehandling, Sørlandet sykehus.

Ingen oppgitte interessekonflikter. 
Litteratur

1. Skeie I, Clausen T, Bukten A. Legemiddelassistert rehabilitering - viktig behandling med dilemmaer. Tidsskr Nor Legeforen 2014: 134: 1156-8.

2. Clausen T, Åsland R, Kristensen O. Pasienter som avbryter LAR-behandling hvordan går det med dem? Tidsskr Nor Legeforen 2014; 134: 1146-9

\section{Re: Nekrose i fingre og tær etter lokalbedøvelse med adrenalin - en vandrehistorie?}

Dette var en flott oversiktsartikkel (1). Jeg har advokert for at lokalbedøvelse med adrenalin ikke gir risiko for nekrose i fingre og tær ovenfor andre avdelinger og sykehus i flere år. Håndkirurgi i lokalbedøvelse med adrenalin har vært praktisert ved plastikkirugisk avdeling på Haukeland universitetssjukehus i årevis uten at det er dokumentert noen skadelige effekter.

\section{Henrik Løvendahl Svendsen}

hlsvendsen@gmail.com

Henrik Løvendahl Svendsen (f. 1978) er lege i spesialisering ved Haraldsplass Diakonale Sykehus.

Ingen oppgitte interessekonflikter.

\author{
Litteratur \\ 1. Finsen V. Nekrose i fingre og tær etter lokalbedøvelse med adrenalin - en vandre- \\ historie? Tidsskr Nor Legeforen 2013; 133: 1827-30.
}

\section{Re: Om kvalitetsarbeid}

Dette er en viktig og god leder om forbedringsarbeid (1)! Det er et tankekors at system og prosessforbedring - basert på Demings Plan-Do-Study-Act (PDSA-sirkelen) - ikke har fått større plass enn det har i norsk helsevesen, selv om den nasjonale pasientsikkerhetskampanjen er et viktig unntak. Legeforeningens innsats kan gjøre en forskjell, først og fremst ved full mobilisering av relevante fagmedisinske foreninger, slik Legeforeningen gjorde da den organiserte de såkalte «Gjennombruddsprosjektene» (2). Kunnskapen som skal til for å drive moderne forbedringsarbeid er ikke spesielt vanskelig, men den må læres! Det «skader» ikke å ha god forskningskompetanse, men moderne system- og prosessforbedring krever en annen kompetanse, som de fleste av oss ikke har blitt eksponert for i de tradisjonelle utdanningsløpene. De fagmedisinske foreningene kan gjøre en forskjell - om de ikke allerede er på banen. Det er ingen tid å miste. Sett i gang. Alle må med!

\section{Hans Asbjørn Holm}

asbjholm@online.no

Hans Asbjørn Holm (f. 1941) er pensjonert lege, spesialist i indremedisin og tidligere fagdirektør i Legeforeningen.

Ingen oppgitte interessekonflikter.

\footnotetext{
Litteratur

1. Gjessing H. Om kvalitetsarbeid. Tidsskr Nor Legeforen 2014; 134: 1199.

2. Legeforeningen. Gjennombruddsprosjekter. https://legeforeningen.no/ Fag-og-fagutvikling/gjennombruddsprosjekter/ (29.6.2014)
}

\section{Re: Spasmer i beina - skade i nakken}

Denne interessante kasuistikken om nakkeskade (1) blir dessverre skjemmet av et uheldig figurvalg. MR-bildet som forfatterne har valgt er et T1-vektet bilde hvor man knapt kan ane spinalkanalen, og i hvert fall ikke se noen medullakompresjon. Hadde et T2-vektet bilde blitt valgt, ville informasjonsverdien vært betydelig større.
Det er uheldig at forfatterne ikke konsulterer radiolog i sitt arbeid med et slikt manuskript, og det er underlig at dette slipper gjennom Tidsskriftets redaksjonelle behandling. En annen ting er at myelopati for de fleste er en klinisk diagnose og ikke et MR-funn. MR kan vise medullakompresjon og medullaødem, men ikke myelopati.

Kjell Arne Kvistad

kjell.arne.kvistad@gmail.com

Kjell Arne Kvistad (f. 1960) er seksjonsoverlege på St Olavs hospital. Ingen oppgitte interessekonflikter.

\section{Litteratur}

1. Gjerde IO, Biørk MH. Spasmer i beina - skade i nakken. Tidsskr Nor Legeforen 2014: 134: 1150 .

\section{M.H. Bjørk \& I.O. Gjerde svarer:}

Kjell Arne Kvistad har rett $i$ at et T2 vektet bilde antagelig ville ha vist medullakompresjon bedre. Vi er også enige i at myelopati er en klinisk diagnose. Vår hensikt med kasuistikken var nettopp å vise et sjeldent, men viktig klinisk funn ved myelopati. Som pasienthistorien viser, er det vesentlig at leger kjenner til kliniske tegn ved skade eller sykdom i ryggmargen. Vi håper dette poenget kommer fram i kasuistikken på tross av suboptimal bildekvalitet.

\section{Marte Helene Bjørk \\ marte.bjork@k1.uib.no \\ Ivar Otto Gjerde}

Marte Helene Bjørk (f. 1980) er PhD og lege i spesialisering ved Nevrologisk avdeling, Haukeland universitetssykehus og postdoktor ved Universitetet i Bergen.

Ingen oppgitte interessekonflikter.

Ivar Otto Gjerde (f. 1947) er spesialist i nevrologi og i klinisk nevrofysiologi og er overlege på Nevrologisk avdeling, Haukeland universitetssykehus. Ingen oppgitte interessekonflikter.

\section{Re: Ytringsfrihed burde funnet Sted}

Dette var en svært velskrevet kronikk (1). Jeg er enig med forfatteren $\mathrm{i}$ at begrensninger i ytringsfriheten i praksis har blitt et stadig større samfunnsproblem gjennom de siste årene.

Jeg har flere ganger lest den korte romanen «Animal Farm» av George Orwell. Det er tankevekkende og trist å konstatere at stadig mer fra den romanen stemmer overens med virkeligheten, at det i vårt samfunn har vært en snikende utvikling der det i små steg blir stadig mindre ekte demokrati og stadig flere totalitære, Sovjetlignende tendenser.

Det viktigste er lojalitet mot systemet. Mindre viktig er hva som er best for pasientene, best for samfunnet, best for folk flest. Det er trist at det stadig blir gjort mer bruk av pervertert og misvisende statistikk og tallmagi, og at slikt i stadig større grad brukes for å tildekke sannheten og rettferdiggjøre bruk at Sovjet-lignende og/eller inkompetente ledelsesformer.

Samtidig er det godt å se at det finnes mange velfungerende arbeidsplasser, også i helsevesenet. Det finnes mange kompetente, samvittighetsfulle, varme ledere rundt omkring, folk som bidrar til mye bra for medarbeidere og pasienter.

Jeg håper at det etter hvert vil bli en kursendring i samfunnet og en holdningsendring i befolkningen, slik at det vil bli stadig flere ledere, arbeidsplasser og avdelinger som preges av en sunn og demokratisk kultur.

\section{Dan Ejstrup-Andersen}

dan@ejstrup.dk

Dan Ejstrup-Andersen (f. 1977) er psykologspesialist.

Ingen oppgitte interessekonflikter. 